\title{
Revista \\ Brasileira

\section{The Pororoca effect on permanent education in health: about the interaction research-work}

\author{
Efeito pororoca na educação permanente em saúde: sobre a interação pesquisa-trabalho \\ Efecto pororoca en la educación permanente en salud: sobre la interacción investigación-trabajo
}

\section{Eluana Borges Leitão de Figueiredo', Ana Paula de Andrade Silva', Ana Lúcia Abrahão', Benedito Carlos Cordeiro', Isabel de Almeida Fonseca', Mônica Villela Gouvêa'}

' Universidade Federal Fluminense. Niterói, Rio de Janeiro, Brazil.

\begin{abstract}
How to cite this article:
Figueiredo EBL, Silva APA, Abrahão AL, Cordeiro BC, Fonseca IA, Gouvêa MV. The Pororoca effect on permanent education in health: about the interaction research-work. Rev Bras Enferm [Internet]. 2018;71(Suppl 4):1768-73.

[Thematic Issue: Education and teaching in Nursing] DOI: http://dx.doi.org/10.1590/0034-7167-2017-0462
\end{abstract}

\section{Submission: 06-25-2017 Approval: 08-06-2017}

\begin{abstract}
Objective: to build municipal responsibility with the permanent education in health policy from the interaction between research and innovation of work practices. Method: experience reports structured through dialogic meetings that allowed the participative diagnosis and strategic administration considering research in health education. Results: from the activities and interactions, we identified active forces in the reinvention of training for workers in the municipal network of health services, in which we found three streams: "inside and outside interactions", "movement towards meetings" and "strategic collective arrangements". Final considerations: through action research and a collaborative critique, collective movements were constructed, they showed ways to produce new directions in health education and allowed the strategic creation of the Núcleo de Educação Permanente as a responsibility of the municipal government, not depending on Federal policies.
\end{abstract}

Descriptors: Continuing Education; Health Personnel; Nurses; Health Policies; Innovation.

\section{RESUMO}

Objetivo: construir responsabilidade municipal com a política de educação permanente na saúde a partir da interação entre práticas de pesquisa e inovação no trabalho. Método: relato de experiência com estruturação de encontros dialógicos que possibilitaram o diagnóstico participativo e a gestão estratégica articulada à pesquisa em ensino da saúde. Resultados: com as atividades e a interação identificamos forças ativas na reinvenção da formação de trabalhadores inseridos na rede de serviços sanitários na esfera municipal, em que foi possível compreender três fluxos: "interações dentro e fora", "movimentos de encontros" e "arranjos coletivos estratégicos". Considerações finais: a pesquisa-ação colaborativo-crítica possibilitou a construção de movimentos coletivos que apontaram caminhos para produção de novos sentidos na formação em saúde e oportunizaram a criação estratégica do Núcleo de Educação Permanente em Saúde, como tarefa de gestão municipal não dependente da política de governo federal.

Descritores: Educação Continuada; Pessoal de Saúde; Enfermeiros; Políticas de Saúde; Inovação.

\section{RESUMEN}

Objetivo: construir responsabilidad municipal con la política de educación permanente en la salud a partir de la interacción entre prácticas de investigación e innovación en el trabajo. Método: relato de experiencia con estructuración de encuentros dialógicos que posibilitaran el diagnóstico participativo y la gestión estratégica articulada a la investigación en enseñanza de la salud. Resultados: con las actividades y la interacción identificamos fuerzas activas en la reinvención de la formación de trabajadores insertos en la red de servicios sanitarios en esfera municipal, y fue posible comprender tres flujos: "interacciones dentro y fuera", "movimientos de encuentros" y "arreglos colectivos estratégicos ". Consideraciones finales: la investigaciónacción colaborativa-crítica posibilitó la construcción de movimientos colectivos que apuntaron caminos para la producción de nuevos sentidos en la formación en salud y permitieron la creación estratégica del Núcleo de Educación Permanente en Salud, como tarea de gestión municipal independiente de la política del gobierno federal.

Descriptores: Educación Continua; Personal de Salud; Enfermeros; Políticas de Salud; Innovación. 


\section{INTRODUCTION}

This study used the concept of the pororoca' effect to discuss the encounter between three research that focus on the work process and on health care. The rapprochement between research practices and everyday work practices culminated in a movement of Permanent Education in Health (PEH) in the municipality of Resende, in the state of Rio de Janeiro, Brazil. The word pororoca comes from the language Tupi (poro + roka) and reveals a noise produced by the waters from the meeting of rivers and sea. When discussing encounters between subjects, Abrahão (2004) recognizes the process of subjectification that is established from the intense and extensive forces of different heterogeneous elements that move through the new existential territories produced during the encounter. Considering this idea, the author uses the pororoca effect as a fold formed against the forces, producing another fold in itself(1). New institutional territories are formed from meetings in which the subjective force is established, thus, causing singularities and constituting new subjective processes.

Considering these ideas, we used the pororoca effect to report the experience of crossing several research projects, lives, knowledge and affections that, when folded over themselves, produced another movement in the training of health workers in Resende, thus, allowing the construction of municipal responsibility through the PEH policy. The interweaving of research that resulted in this experiment occurred from the partnership of the authors in the construction of PEH meetings for workers of Resende from various fields of knowledge. These encounters derived from the understanding that PEH is a social, multidisciplinary, collaborative and collective phenomenon, therefore, necessary for the development of work in health. Several studies consider PEH an important process to strengthen the subjects and make them capable of interacting with and contributing to the social environment where they live ${ }^{(2)}-\mathrm{a}$ dialogic educational process that allows workers to be protagonists of their own training ${ }^{(3)}$. Given this context, the objective of this study is to build municipal responsibility through the PEH policy from the interaction between research and innovation of work practices.

\section{Rapprochement of the research in the city of Resende,} state of Rio de Janeiro

The experience reported was experienced by two women who are nurse researchers and who worked at the Municipal Secretariat of Health of Resende in the construction of PEH meetings from 2014 to 2017. The scenario that allowed the meeting that caused the pororoca effect was Resende, a city located in the region of the Middle Paraíba, countryside of the state of Rio de Janeiro, from two research projects titled: Permanent education in health: creating deformations by Eluana Borges Leitão de Figueiredo, and Permanent education: a strategy to reduce incidents during the preparation and administration of intravenous medication in intensive care units by Ana Paula de Andrade Silva, both studies were developed as master's theses. The study in progress Inside the maze of experiences: collective meetings as territories of affection, knowledge and health care, also by Figueiredo, was also part of the pororoca effect, this research is being developed as part of a doctorate program ${ }^{(45)}$.
We highlight that the meeting of research projects resulted in a unique and ethical process of interference on the work in health in the municipality, producing new subjective processes that resulted in this experience report. Therefore, the different research objects were permeated and challenged by themselves, which resulted in a movement of institutional territories that could support instituting processes related to PEH. Thus, the research produced correspondence and intersections between the university and the work, between teaching/research and labor, between theory and everyday practice.

\section{Materialization of the experience}

The report was built in three parts/flows related to the pororoca effect. The first shows the initial perception of the training processes developed in Resende, from the "inside and outside interactions" of the researchers/workers. The second shows the "movement towards" the city. Finally, the third discusses the "collective strategic arrangements" that resulted in institutional spaces of meeting/training.

\section{"Inside and outside interactions" flow: Permanent Educa- tion in Health in the City of Resende}

The pororoca effect performs movements that are distinct and simultaneous: inside and outside. This effect was the same experienced by the authors, who were at the same time inside (because they work for the city) and outside (because they are researchers of the PEH theme in the city). The inside/outside demanded what Abrahão calls researcher in-world, i.e., a researcher who "tangles, mix, and is affected by the research process, diluting the object itself, since he/she is infected by this process, becoming dirty from the world"(6). This research also evoked some assumptions from action research and collaborative critique, whose commitment to the production of knowledge recognizes both challenging situations that require research, reflections and analyses, and the need to engage in everyday life with a purposeful posture ${ }^{(7)}$.

A fundamental point for the intervention process in the training of health workers of the city started from an investigation of $\mathrm{PEH}$, considering the ideas of administration and health workers. From this knowledge, the nurse researchers/workers, allied to the other workers, began to focus on building meeting spaces. The information was collected through interviews with sixteen workers in the municipality of Resende, after meeting all ethical and legal requirements.

The survey allowed us to listen to the workers about the need for permanent education in their daily practices and on the type of training they aspired. The participants were asked about several aspects, among them, about how PEH is expressed in the municipality and how they would like the educational processes that are geared towards their work to be. The workers mentioned educational processes promoted by the Secretariat of Health in the form of lectures and training courses based on technical updates, as well as pedagogical methods based on knowledge transfer. These processes were considered specific and unable to produce confrontation between differences or put their own work under review. They had little room for intersubjective exchanges or for the discovery of collaborative practices at work, affective

1 The Pororoca is a tidal bore that occurs on the Amazon River in Brazil. The bore is the result from the river waters meeting the Atlantic Ocean at the river mouth. 
meetings and meetings for knowledge and experiences ${ }^{(4)}$. From our surveying of the workers' perceptions, needs and demands, we could verify that the training they wanted encompassed meetings, affections and production oriented by collectivity. Thus, we unveiled the demand for changes on the training processes on municipal level.

\section{"Movements towards meetings" flow: researchers and health workers}

From the knowledge that training for work followed the traditional transmission format focused on training courses, the researchers/workers allied to other workers, public administrators from various sectors, professors and users to collectively discuss ways to start meetings capable of anchoring the $\mathrm{PEH}$ policy in the city. The intent was to reflect on the new meanings of training, and, as the regular meetings occurred, the involvement of the participants increased, and the discussions grew deeper. Thus, a space for the collective production of knowledge was constituted, however, above all, it became an intercessional space of affections and knowledge. This space grew to the point of becoming an interinstitutional and multidisciplinary place of $\mathrm{PEH}$, the EPensando Resende (E-Thinking Resende), which occurred from September 2014 to January 2017. The interinstitutional character of the proposal was expressed by the diversity of composition when promoting conversations between different groups, such as workers, public administrators, users and professors, to build a new institutional territory ${ }^{(8)}$.

From the prospect of giving voice to subjects of the health network and listening to their needs and flows, the nurses/ researchers noticed a powerful device in the creation of $\mathrm{PEH}$ discussion rounds, especially to bring training processes and the everyday practice closer, in a movement of folding over itself, as in the pororoca. This collective construction was driven by the folding of the three scientific research projects cited and led to the creation of the Núcleo de Educação Permanente (Neps Core of Permanent Education in Health) to multiply the meetings as a movement of transformation of an entire health network.

Thus, the Neps of Resende was created to enable permanent pedagogical support and to provide support for the health and administration sectors in the development of activities related to professional training, considering $\mathrm{PEH}^{(5)}$. The activities of the collective EPensando, the creation of the Neps and the participation of the health professionals caused other movements to unfold, building meeting spaces in the municipality, such as PEH discussion rounds within the emergency network - Emergency Hospital, Hospital Santa Casa de Misericórdia, Mobile Emergency Service (Samu), Emergency and Maternity units -, in the Center of Speech Therapy and in the Intensive Care Unit of the municipality. We highlight that the capillarization of PEH discussion rounds in intensive therapy was another important movement in the construction of $\mathrm{PEH}$ in the city, since it led the health network workers to reflect about safe care, having permanent education as the strategy to reduce incidents in the preparation and administration of intravenous drugs in intensive care ${ }^{(5)}$.

From the construction of spaces for meeting-training, which were initially implemented in EPensando and by the intensive therapy discussion rounds, other approaches started to occur. Different workers started to get involved on the process and meet monthly seeking to discuss diverse themes and situations experienced in their workspaces, thus, identifying their training and service improvement needs, in addition to developing action plans. The different PEH discussion rounds were characterized by the unpredictability of the meetings and were anchored in questioning and assumptions of action research and collaborative critique, especially due to the intention of implementing the collective arrangements with the workers and not a formative action on them, as proposed by Pimenta ${ }^{(9)}$. Thus, the permanent education discussion rounds were disseminated and led other workers to think and build their own formative processes.

We must note that the researchers/workers were able to ensure that the meetings were reported in books/files considered portfolios, they contain the registration of participants, the description of activities and photographs. These documents represent the memory of the movement that was composed by $56 \mathrm{PEH}$ discussion rounds in different areas of the municipality, both in health care facilities and spaces of network integration, totaling 772 participations, as shown in Chart 1.

Chart 1 - Number of meetings of Permanent Education in Health for the years 2015 and 2016

\begin{tabular}{|c|c|c|}
\hline \multicolumn{2}{|c|}{ Participation in PEH discussion rounds } & Topics \\
\hline $\begin{array}{l}\text { EPensando PEH } \\
\text { discussion round }\end{array}$ & 284 participations & $\begin{array}{l}\text { Integrative practices in the SUS, } \\
\text { Weaving links with the SUS social network of Resende, } \\
\text { Care for the user in psychiatric crisis: } 1 \text { st and 2nd moments, } \\
\text { Between verse and prose: EPensando the social control in the SUS } \\
\text { EPensando in culture movement } \\
\text { EPensando and mental health: reflecting on the Psychiatric Reform } \\
\text { Health Reform } \\
\text { Health models and the SUS today } \\
\text { Getting words pregnant } \\
\text { The case Margarida } \\
\text { Care and its relationships with the ways of human beings: discussing humanization } \\
\text { The tragic in the production of care } \\
\text { \#oSUSsouEU (\#lamtheSUS) } \\
\text { Territorialization } \\
\text { Assessment rounds }\end{array}$ \\
\hline
\end{tabular}




\begin{tabular}{|c|c|c|}
\hline \multicolumn{2}{|c|}{ Participation in PEH discussion rounds } & Topics \\
\hline $\begin{array}{l}\text { Intensive Care } \\
\text { Unit PEH } \\
\text { discussion rounds }\end{array}$ & 358 participations & $\begin{array}{l}\text { Finding organ donors } \\
\text { Personal hygiene } \\
\text { Care for vesical catheters } \\
\text { The importance of vital signs in the context of intensive therapy } \\
\text { The individual in the intensive therapy context } \\
\text { Interpersonal and interdisciplinary relationships } \\
\text { Asepsis and antisepsis in the hospital environment } \\
\text { Obstructive Sleep Apnea Syndrome } \\
\text { Pneumonia associated to mechanical ventilation } \\
\text { Bandages } \\
\text { Care planning with the nurses } \\
\text { Nursing week } \\
\text { Donation process and corneal transplant } \\
\text { Simulation of care procedures for a user who was victim of a nuclear accident } \\
\text { Backwards legitimacy: building Social Service intervention in the daily life of the HME }\end{array}$ \\
\hline $\begin{array}{l}\text { Municipal Center } \\
\text { of Speech Therapy } \\
\text { PEH discussion } \\
\text { rounds }\end{array}$ & 49 participations & Discussions focused on daily work processes, not in topics. \\
\hline $\begin{array}{l}\text { Emergency } \\
\text { Service PEH } \\
\text { discussion rounds }\end{array}$ & 81 participations & $\begin{array}{l}\text { Nursing records: ethical and legal implications for nursing professionals working in } \\
\text { emergency networks } \\
\text { Care for the user in psychiatric crisis I and II } \\
\text { Workshop in cardiology emergencies and electrocardiogram } \\
\text { Arterial hypertension and cardiovascular risks } \\
\text { Humanized care } \\
\text { Acute Pulmonary Edema } \\
\text { Limb immobilization techniques }\end{array}$ \\
\hline
\end{tabular}

Note: PEH: Permanent education in health; SUS: Brazilian Unified Health System; HME: Municipal Emergency Hospital.

"Collective strategic arrangements" flow: mediation effects and results

We experienced the living experience of meetings between different scientific areas in the municipal territory for two years, from this period we could see that the circular logic of inventive learning was affected by the pororoca effect. This caused the deterritorialization of the research, researchers, trainers, health care workers, public administrators, users and everything that was contacted by the meetings and rounds in Resende. When the pororoca occurs, as the river and sea meet, new mediations are made, new processes are seized, and margins are redone, nothing leaves the intensity and strength of the meetings unscathed. The emerging movement produces plural forces and introduces something new ${ }^{(10)}$. The future of education at work is claimed during the pororoca effect through the sharing of experiences, the creation of collectives and pedagogically listening, questioning and advancing changes in work processes ${ }^{(11)}$.

Researchers and their work were no longer solely responsible for inventing educational processes, other movements also became a part of this. Within the pororoca effect experience in permanent education we no longer knew who was who, if we were researching or being researched, nor the research that originated that movement. The experience of implementing PEH with the workers produced an innovative learning, a result from mediation as multidimensional events and producer of collective affections, thus, instituting education for power.
The support from the municipality administration was a fundamental factor for the construction of the meeting-training spaces. Even without understanding the meetings and their practical effects in depth, the administration secured an institutional place for $\mathrm{PEH}$, allowing training its right to being unfinished and betting in this research model as an in-world learning process, i.e., a learning process that shifts and transforms after every encounter(6).

We must highlight that for all participants involved, the first great learning experience when building these solidary and collective spaces, was the experience of being adrift, having no certainties or guarantees. Regardless of how well-planned and organized the meetings were, they always led us to unforeseen places and made us question the world around us, since the relation between subjects and being in a meeting state produced cracks on the certainties from life and work.

This move required breaking the traditional transmissive nature of learning. Initially, many who came to the meetings sought answers that were ready and expected to find a master who can tell right from wrong. In that sense, they hoped for representations of professions that spoke for themselves, leaving the subject and the human hidden, obscured and silenced in their incompletion. This was a difficult phase of transition. Moving from a position of passiveness as learning subjects to being constructors of knowledge required effort and perseverance from all participants, as well as a considerable amount of time for everyone to understand that the tone of this place for meeting-training was not centered on 
being professional. The interest resided in people, in their marks and incompleteness, in a training to untrain, in a knowledge that would be produced from knowing that they were unfinished and from the critical understanding of themselves and others as imperfect and fallible subjects ${ }^{(12)}$.

Gradually, learning was consolidated in a different manner, emerging as a place of institutor processes and where the subjects invented themselves, creating novel forms of teaching and learning. Collectively, researchers and health workers began to produce forms of meeting what is fluid and sensitive. The permanent openness to art mobilized learning in a special, sensitive and intense manner: the rounds were crossed by poetry, music and affection. This movement empowered the PEH of Resende, being strengthened by repetition and rooting.

The repetition refers to the rhythm of the meetings, i.e., they occurred frequently and permanently, with date, time and location agreed upon. This regularity was fundamental for the construction of bonds between the participants. Inevitably, the repetition caused what we call rooting - the intensity and extensiveness of the pororoca effect. Rooting was the result from the affection generated. Affection was the link, producing not only affective experiences, but marks on people's lives. This made us more porous to learning and generated a spontaneous will to affirm and co-create this place of encounters with the other. If this other was an undergraduate or not, if he/she was a health worker or administrator, if he/she was a professor or user of the services, these things did not matter, what mattered was the intensity of the encounters.

The collective movement began to spark spontaneous interest of participants, they dedicated their time to keep it alive due to wanting the meeting-training space. As a tributary of a river, the experience caused approximations and other streams that strengthened the pororoca, expanding the participatory character of the process of interference in training. These affluent rivers were represented by the collaborative and solidary partnerships established among actors from the Universidade Estácio de Sá, Universidade Federal Fluminense, Universidade Federal do Rio de Janeiro, Committee for Teaching-Work Integration of the Middle Paraíba, Health Risk Management Committee, Technical Group of Pharmacovigilance and the Municipal Secretariat of Health and Ombudsman Office.

The institutional spaces of meeting-training represented knowledge production spaces and promoted the co-creation from the intersection between different actors and institutions.
Thus, the PEH became an instrument to assess work in health in Resende. In this sense, we speak of an institution that covers not only the material world, but especially the immaterial. We must highlight that the immaterial production of work (knowledge, affections, relationships, life styles) is also understood as the construction of a common and collective patrimony ${ }^{(13)}$. Therefore, we are talking of an institution that is produced from relationships and considers the labor world as a favorable space for the learning process of a worker, connecting he/she to his/her own labor action, placing the concept of action under analysis ${ }^{(14)}$.

\section{FINAL CONSIDERATIONS}

The main result of this experience was the power of spaces where collective groups (re) think the labor process, care and life from encounters as a fundamental phenomenon fundamental for health training. Provocative encounters that mobilize people, maintain the differences, promote affection and do not end when the research ends, are movements that make the relationship between researcher-research-object, always be unprecedent and alive. The crossing between multiple types of knowledge, practices and research in $\mathrm{PEH}$ merged in Resende for the promotion of collaborative spaces that resulted in the meetings and produced new protagonists to strengthen the Unified Health System.

From our experience with flows we learned that: repetition, being afloat, rooting and affections are fundamental to maintain training in health alive and permanent. Through the interaction between research and work we could note that, both researchers and health workers built knowledge about teaching, learning, and the political act of critically thinking life and work in a single pororoca movement. In addition, we found that the construction of a municipal $\mathrm{PEH}$ policy with local characteristics can occur without relying on financing, supervision and specific regulations from the Federal government. Finally, we noticed that the UHS can be recognized as a school scenario if work administration is understood as an educational space that favors learning relationships, participation and innovation.

We expect that this experience report can encourage collective movements and pointing paths to produce new directions in health training. The contribution of our research was only one of the aspects presented from the rapprochement with the field of practice, however, new interactions are still happening in the city.

\section{REFERENCES}

1. Abrahão AL. Produção de subjetividade e gestão em saúde: cartografias da gerência [Tese]. Campinas: Universidade Estadual de Campinas; 2004.

2. Paschoal AS, Mantovani MF, Méier MJ. Percepção da educação permanente, continuada e em serviço para enfermeiros de um hospital de ensino. Rev Esc Enferm USP [Internet]. 2007 [cited 2016 Dec 16];41(3):478-84. Available from: http://dx.doi.org/10.1590/ S0080-62342007000300019

3. Brasil. Ministério da Saúde. Portaria GM/MS n 1.996, de 20 de agosto de 2007. Dispõe sobre as diretrizes para a implementação da Política Nacional de Educação Permanente em Saúde e dá outras providências. Brasília (DF): Diário Oficial da União; 2007.

4. Figueiredo EBL. Educação permanente em saúde: inventando desformações [Dissertação]. Niterói, RJ: Universidade Federal 
Fluminense; 2014.

5. Silva APA. Educação permanente: uma estratégia para redução dos incidentes no preparo e administração dos medicamentos intravenosos na terapia intensiva [Dissertação]. Niterói, RJ: Universidade Federal Fluminense; 2016.

6. Abrahão AL. O pesquisador IN-MUNDO e o processo de produção de outras formas de investigação em saúde. In: Gomes MPC, Merhy EE, (Org.). Pesquisadores IN-MUNDO: um estudo da produção do acesso e barreira em saúde mental. Porto Alegre: Rede UNIDA; 2014. p. 155-170.

7. Jesus DM, Vieira AB, Effgen APS. Pesquisa-ação colaborativo-crítica: em busca de uma epistemologia. Educ Real [Internet]. 2014 [cited 2017 Jan 16];39(3):771-88. Available from: http://dx.doi.org/10.1590/S2175-62362014000300008

8. Ceccim RB, Feuerwerk LCM. O quadrilátero da formação para a área da saúde: ensino, gestão, atenção e controle social. Physis [Internet]. 2004[cited 2017 Jan 16];14(1):41-65. Available from: http://www.scielo.br/pdf/physis/v14n1/v14n1a04.pdf

9. Pimenta SG. Critical-Collaborative Action Research: constructing its meaning through experiences in teacher education. Educ Pesqui [Internet]. 2005[cited 2017 Jan 16];31(3):521-39. Available from: http://www.scielo.br/pdf/ep/v31n3/en_a13v31n3.pdf

10. Kastrup V. Políticas cognitivas na formação do professor e o problema do devir-mestre. Educ Soc [Internet]. 2005 [cited 2017 Jan 30];26(93):1273-88. Available from: http://www.scielo.br/pdf/es/v26n93/27279.pdf

11. Ceccim RB. “Um sentido muito próximo ao que propõe a educação permanente em saúde"!: devir da educação e a escuta pedagógica da saúde. Interface [Internet]. 2007[cited 2017 Jan 30];11(22):358-61. Available from: http://www.scielo.br/pdf/icse/v11n22/15.pdf

12. Figueiredo EBL, Gouvêa MV, Silva ALA. Educação Permanente em Saúde e Manoel de Barros: uma Aproximação Desformadora. Rev Bras Educ Med [Internet]. 2016 [cited 2017 Jan 30];40(3):324-31. Available from: http://dx.doi.org/10.1590/1981-52712015v40n3e01712015

13. Teixeira RR. As dimensões da produção do comum e a saúde. Saúde Soc [Internet]. 2015 [cited 2017 Jul 14];24(supl.1):27-43. Available from: http://dx.doi.org/10.1590/S0104-12902015S01003

14. Merhy EE. A organização não existe, a organização existe: uma conversa da micropolítica do trabalho, da educação permanente e da análise institucional. In: L’Abbate S, (Org.). Análise institucional e saúde coletiva no Brasil. São Paulo: Hucitec; 2013. p. 579-96. 